\title{
Tragedy in two African heroic genres: Focus on Achebe's Okonkwo in Things Fall Apart and Kunene's Shaka in Emperor Shaka the Great, A Zulu Epic
}

\author{
Bazimaziki Gabriel
}

University of Rwanda- College of Education, Department of Humanities and Languages Education

\begin{abstract}
Literature comes to readers in various forms of different shapes and conveys messages about human beings' power and deeds that make them rank high or dwindle drastically. Among other literary forms, epics, tragedy and novels depict human heroic exploits but also tragic fall. In this study, the researcher intended to compare Achebe's central character in his realistic novel, Things Fall Apart and Kunene's in Emperor Shaka the Great, A Zulu Epic. The study explores the tragic flaw of Okonkwo and Shaka. Based on a dual theoretical framework namely Christopher Booker's stages of the tragic flaw and Aristotelian theory of the tragic hero, the researcher used literary analysis as the scientific method to cement the discussion. It was found that Shaka,- the protagonist in Emperor Shaka the Great, A Zulu Epic and Okonkwo in Things Fall Apart share a number of tragic features bent with fate and tragic flaw of each. They both committed an error that made them dwindle drastically hence their abrupt death each.
\end{abstract}

Keywords - Literature, novel, epic, protagonist, fame, tragic fall, flaw, fate.

\section{BACKGROUND}

Literary forms come to us in various forms and each of them conveys important messages that help human being cope with the life difficulties they encounter. Literature affects the readership/audience in many ways. When people read literary genres, they know about the ills and mores of human beings over their fellow human creatures. Literature also conveys the messages about how human beings behaved triumphantly in difficult times and overcame challenges. Such messages motivate readers and cause them not to cut moral as they feel there are people who suffered more than them as revealed by what happened to characters they have already read. Elsewhere, some other literary genres affect people in case the latter feel sympathetic when they are exposed to tragic genres and heroic Epic and tragedy are among these literary forms. In this regard, this work looks into how epics and novels embody tragedy in themselves. The researcher will first discuss the interface between epic genres and other literary forms and then pay special attention to epic and tragedy that are key points here. Quoted in Rummel (2002:1), Biebuyck contends that a heroic epic incorporates almost all of the literary forms known to Africans; that it is a multi-generic performance sung by a bard, and then narrated episode by episode. Aristotle, in his Poetics, ranked Epic second after Tragedy. Some critics measured it to myth and legend, others compared it with the novel, a fictitious prose narrative. In this study, epic is not compared to all literary forms. Rather, emphasis was put on the relationship between epic and myth; then epic and legend; epic and romance; epic and novel; epic and elegy; and finally epic and tragedy. Similar points were considered and the demarcation between each of them was discussed.

\section{PROBLEM STATEMENT}

A wide range of studies in literary criticism have been carried out and each of them having its main purpose. Either it is thematic analysis where themes are discussed to a great extent; or stylistic studies with emphasis on analysis of linguistic and/or literary analysis; or language and diction including symbolism and other literary devices. Studies of these types are conducted on literary genres epics included. However, there are very few studies that attempted to look at the tragic fall in epics and novel compared. It is in this regard that the present study was conceived in a bid to draw an interface between epics and novel basing on their protagonist heroic deeds and tragic fall in each of the two genres.

Study objectives

The general objective of this study was to analyse critically the tragic fall of two heroic central characters, Shaka in $A$ 
Zulu Epic and Okonkwo in Things Fall Apart. The study specific objectives were the following:

(i) To Explore the relationship between epic and other literary genres:

(ii) To critically examine how Kunene's Shaka and Achebe's Okonkwo are comparable tragic heroes;

(iii) To identify the messages that the two literary works convey to human society.

\section{Study questions}

In line with the above objectives, the study was guided by the following questions:

(i) What is the interface between epics and other literary forms?

(ii) To what extent are the protagonists Shaka and Okonkwo tragic heroes?

(iii) What messages are conveyed to human society through M. Kunene's Shaka and Achebe's Things Fall Apart?

\section{Theoretical consideration}

This study was framed on some of the Christopher Booker's basic stages of the tragic flaw on the one hand, and Aristotelian theory of tragic hero. Booker says that every story falls into one of seven basic plot structures such as overcoming the monster, the quest, voyage and return, tragedy among others. Not all heroic stories are concerned with all of these stages. Shaka fits most of them and Okonkwo fits some of them. The stages are outlined starting with Booker's structure. Anticipation stage is the first stage where the tragic hero gets it into his or her head that something is missing, and they want it. This might be power, fame, a specific love interest, or something else, but the protagonist has their motivation for the disaster dominoes that are about to fall. Then comes the dream stage. The tragic hero sets out on their path and things start to go strangely well for the protagonist. He might be well on his way down the path of evil, but no one is calling him out on it, or no one can stop him, so he proceeds further into the depths. Now it is the turn of Frustration Stage. Right about here is where the tragic hero hits his first roadblocks. They might be small annoyances, but in dealing with them, the protagonist commits additional dark acts that seal his fate and alert the reader that the only way this can end is badly. Next is nightmare stage. At this level, the tragic hero's plan is unraveling, and he can sense that an opposing force or fate is closing in. He's increasingly paranoid and living in fear of what's to come. Booker says destruction or death is the last stage. According to him, the protagonist breathes his last, whether at the hands of his enemies or due to some final act of violence. Either way, his death isn't mourned much, and the darkness that surrounded him dissipates, and there is much rejoicing. Not all stories fit all these stages. Achebe's Things Fall Apart and Kunene's Emperor Shaka the Great, A Zulu epic fit some of these stages as will be seen later. Concerning Aristotelian theory, a tragic hero is a literary character who makes a judgment error that inevitably leads to his/her own destruction. Aristotle opined that "A man doesn't become a hero until he can see the root of his own downfall." To him, a tragic hero must possess the characteristics such as 1) Flaw or error of judgment (hamartia) Note the role of justice and/or revenge in the judgments. 2) A reversal of fortune (peripeteia) brought about because of the hero's error in judgment. 3) The discovery or recognition that the reversal was brought about by the hero's own actions (anagnorisis) 4) Excessive Pride (hubris) 5) the character's fate must be greater than deserved. Initially, the tragic hero should be either better or worse morally than normal people, in order to allow the audience to identify with them. This also introduces pity, which is crucial in tragedy, as if the hero was perfect we would be outraged with their fate or not care especially because of their ideological superiority. If the hero was imperfect or evil, then the audience would feel that he had gotten what he deserved. It is important to strike a balance in the hero's character. Eventually the Aristotelian tragic hero dies a tragic death, having fallen from great heights and having made an irreversible mistake. The hero must courageously accept their death with honour. Some other common traits characteristic of Aristotelian tragic hero include much more suffering than he deserves, being doomed from the start but bearing no responsibility for possessing his flaw. The hero must be noble in nature but imperfect so that the audience can see themselves in him; he must have discovered his fate by his own actions, not by things happening to him; must understand his doom, as well as the fact that his fate was discovered by his own actions. The hero's story should arouse fear and empathy. Hero must be physically or spiritually wounded by his experiences, often resulting in his death. He must be intelligent so he may learn from his mistakes and must have a weakness, usually it is pride. He has to be faced with a very serious decision that he has to make too.

\section{LITERATURE}

This section reviews some literature particularly epics and other literary forms. Epics are multi-generic great literary forms of narratives. Biebuyck quoted in Rummel (2002:1) posits that the heroic epic incorporates almost all of the literary forms known to Africans that it is a multi-generic 
performance sung by a bard, and then narrated episode by episode. Many other critics measured it to it to myth and legend. Renaissance critics, for example, considered it as the highest genre while Aristotle, in his Poetics, ranked it second after Tragedy. Some critics compared it to the novel, a fictitious prose narrative, while others, like Aristotle measured epic to tragedy. In this study, epic was not compared to all literary forms. Rather, emphasis was put on the relationship between epic and myth; then epic and legend; epic and tragedy; epic and novel; epic and elegy; and finally epic and romance. Similar points were considered and the demarcation between each of the two was discussed with particular interest on themes and characters.

\section{Epic and Novel}

Literature is a very broad field whose halves include novel and epic among other components. Harmon and Holman (1992) define epic as a long narrative poem in elevated style presenting characters of high position in adventures forming an organic whole through their relation to a central heroic figure and through their development of episodes important to the history of a nation or race. A novel is a long prose story that is imaginary. Some elements of epics are reflected in the novel. Quoted in Bazimaziki (2017), Rummell calls epics "cultural monuments" and says that they preserve and celebrate cultural values and customs. She adds that epics serve to unify the listening community by reminding them of the value of their culture. Achebe's Things Fall Apart, though not an epic entirely, falls under this category of genres. The book preserves not only the Igbo tradition and customs but also the culture of Africans as a patriarchal society; the ties between the uncle and nephew being important. Holman (1972:355) noted that novels are representations in fictional narratives of life or experiences [...] that serious fictions deal with man in significant actions in his world. He goes on to say that the novel may concentrate upon a character, almost to the exclusion of incident and plot. Joseph Mbele (2005) explains that a novel can display some of the characteristics of epic literary form. According to him, Okonkwo undergoes such tests, including the wrestling match with Amalinze the cat, his struggle with the negative legacy of his father. The novel starts in epic proportion and ends in tragic fall. The writer begins the book with admiration toward Okonkwo's realistic deeds who dies poorly at the end of the story by committing suicide after he copped the head of one court messenger before the public. Mbele (2005) explains that Things Fall Apart can be seen as an epic and resemble stories about heroes found in many cultures. In such stories, the heroes are extraordinary individuals whose careers are bound with fortunes and destinies of their society. They become heroes by accomplishing great things for themselves and their communities winning much fame as a result. Okonkwo is a character of this type, an extraordinary individual whose accomplishments astonished men in Umofia and even beyond; an exceptional and courageous man to whom many people in their nine villages pay respect as he is a great fighter from Umuofia to Mbaino. Achebe (1958: 3) describes him as a well-known man throughout the nine villages and even beyond. His fame rested on solid personal achievements. As a young man of eighteen, he has brought honour to his village by throwing Amalinze the cat - a great wrestler who was unbeaten for seven years, from Umuofia to Mbaino. Bakhtin (1981) says that the epic, unlike the novel, is a highly-distanced genre, i.e. its form and structure situate it in a distant past time that assumes a finished quality, meaning that it cannot be re-evaluated, re-thought or changed by us. An epic (aristocratic and monologic form) exists in cyclical time, but the novel exists in linear time moving from past to the present into the future.

\section{Epic, Myth and legend}

Epics, legend and myths are the halves of one set - folklore and the line between the three forms is not easy to draw. Basing on their definitions each, and considering the heroes in each of them, it seems hard to contrast these folkloric components. Often times, myths, legends and epics are intertwined in that some of one's elements are found into the other and vice versa. Epic and myth are interrelated forms bent on great heroes ranked by their great wonders, a good blend of both personal and superhuman achievements. In most cases, these heroes are particular breeds of different heroes from those we can encounter in fictional narratives. Epic, mythic and legendary heroes have particular traits, and are extraordinary persons that we meet in various cultures and in different periods. Myths and epics are related in the sense that both are bent on the quest theme and the immortality of their heroes associated with the magical power. However, some slight differences may be seen between the two. Holman (1972: 333) echoed that myths are anonymous stories rooted in the primitive folk-beliefs of races of nations and presenting supernatural episodes as a means of interpreting natural events in an effort to make concrete and particular a special perception of man or a cosmic view. The Concise Oxford Dictionary (1999: 944) defines myth as a traditional story concerning the early history of a people or explaining a natural or social phenomenon, and typically involving supernatural being or events. Many myths describe the creation of earth and some describe the origin of earth and human race. As one example, 
myth puts it that the earth emerged from the flood (The World Book Encyclopedia, 2016). Myths are concerned with the themes of creation, religion, and with the meaning of life and death. Myths also chronicle natural phenomena and heroic adventures. For example, the myth of how Kivu Lake (in Rwanda) came to be has it that the famous Nyiransibura urinated it. Similarly, the Myth of China tells how the earth and sky originated from an enormous egg. Myth is anonymous and has a less historical background while epic historical background is known. Legend and myth are very sophisticated narratives sometimes bent on fantasy. Legend has it that the lake was formed by the tears of God (Oxford Advanced Learner's Dictionary). In epic texts the hero is at first glance a man who, despite his initial inferiority, defeats opponent who are more powerful than him, thanks to his alliances with invisible forces. Consequently, the use of the fantastic draws attention to the fact that what is more desirable for humans is to attain immortality because this is the only way the hero of the mortals can escape the constraints of time and space (Deme, 2009: 16) Unlike myths which are said to be old, legends are stories told as if they were true, be they set in the real world or relatively in recent times. A number of legends are probably associated with famous people who have died. In this vein, legend can be measured and associated with epic as Hogins (1984: 4) asserts that somewhat related to the legend is the epic, a long narrative poem that mixes adventures, morality and tragedy. He adds that it is characterized by definite elements including epic battle. Niane (1965) accounts that part of Sundiata: An Epic Of Old Mali is legend and part of it history. Emperor Shaka the Great, A Zulu Epic is also full of legendary and historical facts. Beowulf, an epic of Old English, is not exception. Both Beowulf and Emperor Shaka the Great, A Zulu Epic center on heroic adventures, great deeds and exploits of Beowulf and Shaka, exceptional warriors of their times each. Their names are still shaking different corners in literature as historical heroes among others.

Scholes (1978: 136) accounts for the legendary hero that the legendary hero is to be found in the writings of certain historians who emphasize battlefield heroes in their histories. These heroes are actual historical personages in that people bearing those names may have lived and even been present at the events described. But the deeds recounted are so coloured by myth and epics that no modern historians dares to accept them uncritically. One point needs be made clear. While it is already stated that epics and legends are connected with fantasy, it will be hard for historians to believe them as they rely on real facts and events, past and present to shape or plan the future. Kesteloot (1971:21) discusses epic hero and says: Bien sûr, dans l'épopée [Mandingue] nous rencontrons beaucoup d'éléments legendaires. Ils sont surtout concentrés sur la naissance et l'enfance de Soundiata. Pourtant, sa paralysie jusqu'à sept ans semble un fait reel et le fait qu'il est guéri. (Of course, in epic [Mandingo epic] we meet many legendary elements. They are particularly concentrated on the birth and childhood of Sundiata. However, his paralysis until seven years of age seems to be a real fact besides that he cured of it.)[Translation is mine]. As revealed through the above quotation, Kesteloot bases on Sundiata as an example and sides with the idea that epic and legend are somehow more interrelated than are distanced to each other. In what he says, the idea is that epic embodies legend, a good blend of the fantasy and the real facts. Taken together, epic, legend and myth are the components of one set which is folklore. The latter reflects the attitudes and ideals of society dealing with tradition, customs, and beliefs. Both epic and myth tell about heroic deeds of men and gods in war or travel. Legend is no exception and is associated with heroes be they holy personalities, religious leaders, or human beings who more often than not face supernatural creatures. Among the three, myth is somehow distanced as it is more concerned with the origin of things and explanation of phenomena unlike the two others.

\section{Epic and elegy}

Epic and elegy can be measured in terms of themes, length and tone. Epic themes consist of general problems including social conflicts, heroism, war, love and man's destiny while in elegy the main concern is meditation, the expression of grief or love. Thus, most elegies praise the departed hero and their tone is often sorrowful and lovely while in epics tone varies from poem to poem. Either it is critical, praising, admirable, sad or sorrowful, joyful, and so forth. Concerning length, epics are long narratives unlike elegy which are normally short poems about meditation occasioned by the death of a hero. The end of some epics is unhappy. Sometimes epics end with the death of the hero accompanied with funerals. This is another important point an elegy is concerned with. Beowulf is a good example for it ends with the Geatish warrior's lament for their great, kind, gentle and considerate king Beowulf. He died in his last battle against Dragon when he was mortally wounded (Sporre, 1988:217). Kunene (1979: 431-432) echoes the same idea on Shaka's death and dirge: "Skaka! They are shouting your name, they are calling you, (the mountain has fallen, the earth trembles). The wind carries the voices of women. The wound is tended by women, the wound is dark. Our child is dead; our sun breathes the final agony [...]." Such words imply the 
greatness of the gentle king Shaka after he passed away. The mountain has fallen, for example, reflects his fame. He is equated with the sun as he had been enlightening his people much as the sun rises and sets rays on earth. As these sun rays illuminate the world, the idea is that Shaka's service to his nation was priceless. To put it simply, epic and elegy may be compared in terms of themes, tone and length. The themes of epic are mostly concerned with general human issues, war, heroism, and so on. Unlikely, themes in elegy consist of the death lament of an important personality. The end of an epic may also bring some meeting points between the two literary forms. Tone in epic varies from poem to poem whilst elegy has a sorrowful tone. In terms of length, an epic is longer than elegy. In other words, elegy may be measured to a subset of epic especially in their very ending parts.

\section{Epic and Romance}

Both epic and romance are narrative forms. Schweizer (2006: 20) postulates that epic and romance are two closely related genres. Romance denotes a fictitious narrative in prose or in verse, the interest of which turning around incidents either marvelous or common. Romance includes popular epic (Chanson de Geste) and artificial poems composed to be sung before an aristocratic audience. Both kinds of epics concentrate on celebrated heroes. However, most romance centers on the theme of love affairs or adventure unlike epics in which wars, hatred, man chasing his fellow human being, people rendering a securing service to others, royal family conflicts, etc. are the recurrent themes. Mulokozi (2000: 9) explains that most epics tend to reinforce oppressions, class and gender divisions in society[...] and that certain themes such as love, bareness, kinship, life and death are of course universal. Romances also consist of imagination of the author and are as such fictional. Unlikely, epics are originated from folklore. They are the production of the community hence their historical origin. Epic characters are thus historical while characters of romance are fictional. Holman (1972: 475) posits that Romance is a fictitious narrative of which the scene and incidents are very remote from those of ordinary life. He adds that romance is more freely the product of the author's imagination than the product of effort to represent the actual world. Sporre (1988: 217) gives a good example of this kind. He believes that The Song of Roland, a French old epic whose author is identified as Turold tells the tale of a legendary battle between the French and the Saracens with a model hero of unyielding warrior. Taken together, epic and romance are comparable from what they are about and from their origin. Epics are most often historical narratives while romances are fictional. The focus of each of the two, themes in particular, may distance them in one way or another.

\section{Epic and Tragedy}

Aristotle quotes, "A man cannot become a hero until he can see the root of his own downfall." According to Aristotle, a tragic hero must be noble, occupy a high-status position and there should be a tragic flaw that eventually leads to his downfall usually due to his over-confidence. Tragedy, he goes on to say, is usually raised by some error of judgment or some character's flaw and the audience must feel pity and fear for this character. Hamlet and Macbeth are such characters often portrayed as tragic heroes through their nobility, tragic flaws, and errors in judgment. Okonkwo in Achebe (1958) fits some of these characteristics hence some critics echoed that Things Fall Apart can be seen as a tragic heroic story (Foley, 2001) and as" the tragedy of one man who worked out his personal conflicts, the man whose suicide is a gesture that symbolizes personal refusal of a new order as well as the collapse of the old order which he represents as his tragic flaw is a reflection of his society and his defeat (Ireleqtd in Rajeshwari \& Bhuvaneshwari, 2016) particularly because of its tragic central character whose admiration in the beginning of the story culminated into a drastic fall at the end of the story thereby committing suicide after he chopped the head of a white court messenger, a result of his pride and fate. In the same vein, Harmon and Holman (1992) define tragedy as a type of literature which focuses on exalted or noble people who experience a fall from grace as the result of their own mistakes, flaw, or destiny. Elsewhere, the same authors say that epic is a long narrative poem in elevated style presenting characters of high position in adventures forming an organic whole through their relation to a central heroic figure and through their development of important episodes to the history of a race. While epics are narrative poems originated from folklore, Muich (2010: 12) holds that the texts of both tragic and epic genres tell stories considered as traditional tales, stories transmitted orally for generations and their authors are in certain instances unnamed. Unlikely, authors of tragedies are known. Tragedies are written to be acted before the audience and involve imitation of the real life. Epic agrees with tragedy in that all elements of epic are found in tragedy, the latter turning on the suffering of human with a sad ending in most of cases. Dorsh (1965: 43) stands for it that epic poetry agrees with tragedy in that it is a representation of a serious action in a dignified verse [...] Thus anyone who can discriminate between what is good and what is bad in tragedy can do the same with epic, for all the elements of epic are found in tragedy (though everything that belongs to tragedy is to be found in epic...). Additionally, tragedy centers on one character, a man with exceptional qualities in a high 
position who undergoes a serious fall from power and respect, and such a fall affects the whole nation. Gill (1995: 257) says that the main action of tragedy is the fall of a hero internally and externally. Externally, he goes on, the hero falls from both power and respect; and internally he falls from peace of mind. Some of epics heroes fit this feature. Shaka is one example. Some days before he died, his power and respect dwindled. His mind was not stable too. Those who had been the first to respect him started complaining against his governance. Consequently, they plotted to kill him and did it so. Okonkwo is another example of that type of character. Some days after his return from exile where he had spent seven years, his respect and reputation decreased as people were no longer holding together since the white colonialist brought a knife which cut the things that held them together and they began to fall apart (Achebe, 1958: 125). It is a fall of the clan particularly Okonkwo who was a very influential man among the Umuofians; a resistant to the change brought by the Christian church to the expense of traditionalism.

Dorsh (1965:3) quotes Aristotle and says that the purpose of tragedy is to make the audience feel pity and fear for the characters. He adds that the hero of any tragedy- Ancient Greek tragedy specifically- is a great man who suffers because of tragic flaw or error in judgment. In this regard, one may agree that epic is comparable to tragedy for epics begin in admiration and end in a great sorrow people lamenting the death of their loved hero. Beowulf is an example in this case. The poem ends when the soldiers are lamenting the death of their gentlest, intelligent and great warrior, Beowulf. He had secured people from Glendel and his mother, and then from the Dragon. It is in that last battle that Beowulf died in a battle after he had mortally wounded. Scholes (1978) is of the same view that tragedy ends in death and mourning. Elsewhere, tragedy may be measured to epic in terms of plot. Dorsh (1965:3) asserts that its plot should be dramatically constructed like those of tragedies: they should center upon a single action, whole and complete, having a beginning, a middle, and an end so that like a single complete organism the poem may produce its own special kind of pleasure. Epics and tragedy may further match in the sense that both are bent on fate. People in tragedy contented against fate that they could not escape. The destiny of epic protagonists are likely inevitable and fortunately Okpewho (1979:28) says that the African epic hero is not the puppet of the god but a master of his destiny. However, Muich (2010: 17) draws the difference between the two genres that the mystery behind the composition and the textual codification of the epics, the interest in their historical value and connection to archaeological finds and anthropological theories, as well as the sheer number of characters, events, motifs, and themes have provided enough material to distract scholars from addressing character directly. Tragedies are not as lengthy, deal with a shorter narrative time frame, contain fewer characters, motifs, and themes, and were created and performed in a known, if not completely understood, historical and cultural context. Taken all in all, epic and tragedy are two members of distant families. One is a component of Drama and another is a half of narrative poetry. Epic is written handed down retold from generation to generation while drama, as a set to which tragedy belongs, is written to be performed before the audience. Epic may be anonymous unlike tragedy. In each of the two, everything turns around a hero. Fate in tragedy on the one hand, and destiny in epic on the other hand make the two literary forms meet in some points.

\section{METHODOLOGY}

The study is qualitative and consists of literary analysis with much reliance on Professor Jekins Rob's scientific method as well discussed in Bazimaziki (2017). Jekins considers literary analysis as a scientific method in literary studies which he posits to broadly consist of three main steps such as observe, hypothesize, and experiment. He explains that a poem or a work of art can be interpreted simply by applying the scientific method as defined above. The methodology here is justifiable in this sense. When we read a text, we must read it multiple times, read it slowly and carefully, constantly asking ourselves, questions about what the writer is trying to mean. Any reader as a critic must pay special attention to particular words, passages, or elements that seem especially significant or perplexing and ask him/her what they signify, how they fit in with the work as a whole. In so doing, we begin over time to come up with a theory of what the text might be about. The real work lies in experimenting, or testing the hypothesis. Now experiment starts at the top and test your hypothesis against what the poem or literary work actually says. Literary analysis is as such an approach that the researcher considered the three steps fitting for a literary study of this type. The corpora in this study are two literary works in African Literature. Achebe's realistic but also historical novel, Things Fall Apart was a corpus on the one hand. This novel was mainly taken on the ground that it is a tragic novel as it starts in admiration of the central character and ends in a serious fall. Emperor Shaka the Great, A Zulu Epic was another corpus. As a an epics that depicts the historical figure in South Africa, the poem served as a primary source of data that was compared to Things Fall 
Apart - though the two are not the halves of one coin. Thus, comparative approach was used in that the two protagonists namely Okonkwo and Shaka were measured each other with special interest in fate that they could not escape at all.

\section{DISCUSSION: ANALYSIS OF SHAKA AND OKONKWO}

Using Aristotelian theory of the tragic hero, this section analyzes Shaka and Okonkwo, the central characters depicted in African writings. Shaka is the protagonist in South African literature in a Zulu heroic epic authored by M. Kunene specifically. Unlikely, Okonkwo is the protagonist in Achebe's Things Fall Apart, a famous realistic novel in West African fiction, in Nigeria specifically. The heroes display the heroic characteristics but also tragic fall each. Thus, comparing them basing on the two factors can lead to the following description of each basing on their heroic characteristics. Initially, I have given a brief summary of each of the two literary works to help reader(s) have an idea on it. Following closely, I have dealt with the description of characters' lives from birth to death with particular interest in important actions and remarkable. Starting with Shaka, the epic follows the life narrative of Shaka the Great and is narrated from a third person perspective. The book begins with the apparently legitimate love affair of Nandi with Shaka's father Senzangakhona. However, Senzangakhona mistreats Nandi and drives her from the Zulu kingdom. She flees the kingdom and spends years travelling amongst kingdoms friendly to her own tribe. While abroad, she gives birth to Shaka and brings him up. They finally settle in the kingdom where Shaka grows, quickly showing himself as being sharp minded and military prowess. He quickly gains command of his own regiment which he retrains in a new fighting system. Instead of fighting with throwing spears from afar, which was the traditional method of warfare, Shaka suggested that a large shield and a short stabbing spear should be used. His strategy relies on a quick approach to the enemy under the shield so that they could stab the enemy before the latter could throw many spears. Shaka earns reputation as both a fighter and warrior. When Senzangakhona dies, Shaka, with pardon of the King whose kingdom he has lived in, leads a military force into Zululand. Soldiers and the populace flock to this great warrior and Shaka ascends to the throne usurping his more legitimate brothers. With his ascension to the throne Shaka radically reorganizes the military system. With this new organization and the tactics he perfected with the short spear. So he begins expanding into neighbouring regions, suppressing Kings and bandit armies while assimilating these peoples into the Zulu nation. Soon, the first white people come in contact with the Zulu led by a man named King. Though Shaka does not totally trust these people, he allows them to settle in a small part of his land so that he can learn about their ways. He also sends an Uncle as a mission to King George of England. Meanwhile, Shaka's mother, Nandi, dies and Shaka declares a national year of mourning. As the nation mourns, the economy begins to fall apart. Finally Shaka is persuaded to allow everyone to replant the fields and have children. Gradually, Shaka's brothers and aunts become frustrated with his rule and plot to overthrow him. One of Shaka's most trusted advisers agrees to help them, and they kill Shaka while he is holding court.

Shaka is thus a hero whose fame spread here and there in South Africa, and even beyond especially in different corners of Africa. His military genius made him a special historical personality. Few military strategists of his time were measured to him and he was a real visionary. Kunene (1979: xvi) describes him as the great military genius, the great political organizer, the great visionary. Shaka was seen as a more consummate and stronger leader than his neighboring state. As a political and military leader, he was unchallenged master of the region and Kunene (op.cit.:xiii) postulates that among the outstanding leaders and Generals in the African continents, no one captures the imagination as Shaka of Senzangakhona .... and areas that were not under his direct rule were under his protection. Further, Shaka was an indulgent leader for - not only was he a great military genius, but also his varied gifts demonstrated qualities of organization and innovation (Kunene, xiii), a model for many other Generals and leaders in the sense that those who adopted his military tactics established their own kingdoms. However, much as no one is gifted in all things, Shaka was accused of mass killing. He killed many of his soldiers whom he accused of cowardice. Whoever made a single mistake or suspected to have committed a crime during his reign deserved nothing but death as punishment. He was so terrible that people, Generals, and even his relatives feared him. He was praised for his bravery but also denounced for his fierceness. Shaka was also named the Little Fire - the fire whose fierce frame cannot be curbed. Probably, this fierceness rooted in his bitter childhood when his mother was considerably hated by his father. Shaka was given many other names like Lion and his mother was confident that one day he would be great and feared. Ritter (1965:1) shows Nandi comforting Shaka saying: - Never mind my Little Fire, you have got courage of a lion and one day you will be the greatest chief in the land... I can see in your eyes, Nandi goes on to say, when you are angry, they shine like a sun and 
yet no eyes can be tendered when you speak comforting words to me. Shaka is then described as a future highly ranked hero due to his physical status, intelligence and military genius. As shall be seen later, his heroic deeds tell more about this fame all along his life.

Concerning Okonkwo's story, we are told that he is a son of a very lazy debtor Unoka, a man who was badly reputed in Igbo village in Umuofia. As he grew up, Okonkwo worked hard to bring change for himself and his family's respect. Achebe (1958:1) says that Okonkwo was well known throughout the nine villages and even beyond. His fame rested on solid personal achievements. As a young man of eighteen he had brought honour to his Village [...] has taken two of the four possible titles of his clan and is the patriarch of a large family. Okonkwo is then appointed guardian of Ikemefuna, a boy from a rival village. When the Oracle demands that Ikemefuna be sacrificed, Okonkwo kills the boy himself so as not to appear weak. OgbuefiEzeudu, the oldest man in the village, dies. At the funeral, Okonkwo's gun explodes and kills Ezeudu's sixteen-year-old son. To appease the earth goddess Ani, Okonkwo is exiled to his mother's village of Mbanta for seven years. He later returns to a village plagued by white missionaries and their provincial government after seven years of the sweet and bitter of life exile at his uncle Unchendu. Okonkwo and other village leaders burn the new church down, but are jailed and humiliated for it. Okonkwo then kills a colonial messenger, but the divided village fails to rally behind him. So, he hangs himself, an act that violates Igbo traditions and prevents him from receiving a proper burial. This is undoubtedly a tragic situation as the hero whose fame and wanders are reduced until he is burial is not given much consideration because of customs. Rajeshwari and Bhuvaneshwari (2016)analyzed how a tragic dimension is furthered in the novel by the protagonist because of his tragic flaw and contend that it sheds light on the reasons of the tragedy that unfolds on the Igbo society. The two authors elucidated how Oknokwo [sick], the strongest man in the community, tries to oppose the white man but some of them were won over by the white man's faith and the clan is no longer united as before. When his people refuse to follow the protagonist, he commits suicide in anger, frustration and despair. At this level, frustration stage in Booker's tragic hero is justified. Okonkwo has been frustrated since long before he commits suicide. In part three of the book -The return from exile, Okonkwo feels he is betrayed by his chi (god) and his people. $\mathrm{He}$ believes he can still change things but in vain. The colonialist has used the power of the gun and the Bible to change people and the latter have already joined. Unlike other village people beliefs, Okonkwo thinks he still has power as before but realizes that he is almost alone. Aristotle's theory of tragic hero holds that the hero must be intelligent so he may learn from his mistakes. He must also have a weakness, usually pride and has to be faced with a very serious decision that he has to make. Okonkwo then fits this kind of hero. He learned from all the mistakes he has made starting from the female crime that causes him to flee from Igbo to Mbanta, his motherland. Okonkwo is also faced with a serious decision he has to make. The right decision to him, and wrong decision to the clansmen, is to commit suicide which put an end to his fear of failure.

\section{Shaka and okonkwo's important events}

Important deeds of Shaka are mostly connected with his supernatural power. As a subject of destiny, his action is driven by superhuman power especially at war time. To start with, Shaka's important action at his thirteen years of age is characterized by a special courage. At this time, he attacked and killed a black snake which had beaten and killed the best bull of the cattle he was caring. Of this courageous deed, Skaka received a reward from the hands of one chief (Ritter, 1964: 1). It is hard to believe that a thirteen child can afford dangerous animals and kill them. Shaka's power then at that time was so great to the extent that instead of fearing a snake, he broke it into pieces. Considering the deed and the age, thus, it is an exceptional and important action which occasioned him to be the chief of the herd boys. Shaka's action goes on. Now he kills a leopard. This is at his young age. He has already become one of the herd boys of the chief of the Mtethwa land where they exiled. Now the death of a leopard is inevitable. The leopard often attacked the cattle and killed them. People did not know what to do. When it attempted again, Shaka fearlessly killed it with a stick. He was then praised for that. -When the men arrived, they were loud in the praises of the brave deed (Ritter, 1964:4).

It is important to say here that a stick can't kill a leopard unless one is gifted and well talented in an exceptional way. As one can see, such a deed is courageous. He who killed an animal of that kind is without any doubt a brave and fearless man. As chief Ngomane had already grown fond of Shaka, he rewarded him a cow. Now comes his third important deed as shown below. There had been a forest bandit, a $-\mathrm{Mad}$ Giant regarded as a witch doctor who had become a threat for the whole region. Many soldiers had been sent to fight him vainly, but Shaka manifested no fear before him. Though dissuaded not to face the bandit, Shaka would teach him a good lesson and gave him no chance, stabbed him again and again with his fame spear. The giant fell collapsing like a huge tree, like a bounder coming to rest in a deep valley 
(Kunene: 63) Aristotle says that the tragic hero should initially be either better or worse morally than normal people, in order to allow the audience to identify with them. This also introduces pity, which is crucial in tragedy, as if the hero was perfect we would be outraged with their fate or not care especially because of their ideological superiority. Shaka fits this feature. Over and above, his important action centers on his war time as he is seen as a great and peerless warrior. Among the wars he fought and won, one may mention the war against the Ndwandwe army, the conquest of E-Langeni, his wars against the Buthelezi, the battle of Quokli (where he fought the Zwide army), and many others. Thus, his military action is linked with his building a highly trained army. Kunene(1979) contends that from a small volunteer army of about 200 and a territory that seemed...no more than small, Shaka built in a period of ten years, a formidable standing army of about 60,000 to 70000 highly trained men. Put another way, the action of Shaka is so important that he won much respect but also feared for it. His strengths, war skills, power and bravery made him a special character from his very teenage onward. Few men of his time could be like him. Aristotle believes that a tragic hero must be noble in nature, but imperfect so that the audience can see themselves in him and must have discovered his fate by his own actions, not by things happening to him. Further, he must understand his doom, as well as the fact that his fate was discovered by his own actions. His story should arouse fear and empathy too. Okonkwo's important actions and events are not exception. Achebe(1958:1) says that Okonkwo threw Amalinze in a fight which the old men agreed was one of the fiercest since the founder of their town engaged a spirit of the wild for seven days and seven nights. That was many years ago, twenty years or more, and during this time Okonkwo's fame had grown like a bush-fire in the harmattan. When Unoka died he had taken no title at all and he was heavily in debt and Okonkwo was ashamed of him. At this level, Okonkwo's situation reflects Booker's first stage (Anticipation Stage) where the tragic hero gets it into his or her head that something is missing, and they want it. This might be power, fame, a specific love interest, or something else, but the protagonist has their motivation for the disaster dominoes that are about to fall. Okonkwo wants to clean the shame brought to his family by his lazy and poor indebted father. He is always afraid that if nothing is done he can be like his father. As the saying goes that "Like son, like father", Okonkwo's dream and ambition proves it differently. $\mathrm{He}$ wants to work hard and get rich. That is why he hates all that seems his father's behaviour for Achebe (1958:5) believes that his whole life was dominated by fear, the fear of failure and of weakness. Even as a little boy he had resented his father's failure and weakness, and even now he still remembered how he had suffered when a playmate had told him that his father was agbala [meaning a man who had taken no title]. And so Okonkwo was ruled by one passion - to hate everything that his father Unoka had loved gentleness and idleness in particular. During the planting season Okonkwo worked daily on his farms from cock-crow until the chickens went to roost. He was a very strong man and rarely felt fatigue. To Okonkwo, something wrong with his family is poverty coupled with a lot of accumulated debts by the lazy father. He has got a task by himself to go against the common saying that "Like son, like father" change clansmen belief that the Unokas are among the group of efulefu in Umuofia (worthless people) and did it so. Inherently, Okonkwo is not only a hardworking man in land works and wrestling match but also a famous warrior to the extent that people in the whole village and the neighbouring villages know him. Mbaino people can witness it well as when they have killed a sister who comes at the market from Umuofia, it costs them a lot. We are told that:

Umuofia was told how their daughter had gone to market at Mbaino and had been killed. And so the neighbouring clans who naturally knew of these things feared Umuofia, and would not go to war against it without first trying a peaceful settlement. But the war that now threatened was a just war. Even the enemy clan knew that. And so when Okonkwo of Umuofia arrived at Mbaino as the proud and imperious emissary of war, he was treated with great honour and respect, and two days later he returned home with a lad of fifteen and a young virgin. The lad's name was Ikemefuna, whose sad story is still told in Umuofia unto this day. The elders, or ndichie, met to hear a report of Okonkwo's mission. At the end they decided, as everybody knew they would, that the girl should go to Ogbuefi Udo to replace his murdered wife. As for the boy, he belonged to the clan as a whole, and there was no hurry to decide his fate. Okonkwo was, therefore, asked on behalf of the clan to look after him in the interim. And so for 


\section{three years Ikemefuna lived in}

Okonkwo's household. (Achebe, 1958)

Going to war for the whole village is an important and sign of heroism. Not everybody can accept to do so as it requires special and strong attachment to the home village. Okonkwo was very confident that in case Mbaino refuses to settle the issue peacefully, he would fight and revenge for the departed sister. Inherently, they pleaded guilty and accepted to compensate Umuofia with both a lad of fifteen and a young virgin. Due to his reputation among his clansmen, Okonkwo is then assigned the responsibility to look after he lad, Ikemefuna and accepted. This is an important event that increased his confidence, worth and respect in his own village and the neighbouring places as well.

\section{The tragic fall of the two heroes}

In most cases, epic heroes die extraordinary death and their funerals are highly commemorated. Beowulf, the indulgent, generous and the kindest king is a good example. His death resulted from his fight against the dragon when he was mortally wounded. He was highly mourned and lamented and the Geats who shared his hall mourned the death of their Lord, and said that of all the Kings he was the gentlest and the most gracious of men, the kindest to his people, and the most desirous of renowned (Wright, 1957: 93). Each of Okonkwo and Shaka's death is a bit different from the above case. Their deaths are tragically rooted in their error of judgement. One of the characteristics of a tragic hero is discussed in the Poetics where Aristotle uses the word "mistake" (hamartia in Greek) often times translated as "flaw" or as "error." The great man falls through--though not entirely because of--some weakness of character, some moral blindness, or error. He adds that one should note that the gods also are in some sense responsible for the hero's fall. Booker's destruction stage holds it that the hero's death isn't mourned much, and the darkness that surrounded him dissipates, and there is much rejoicing. Achebe's Okonkwo is concerned with this situation. He said that he was betrayed by his god (chi) and after he decided to kill the court messenger, he committed suicide. Achebe (1958) says that in a flash Okonkwo drew his machete. The messenger crouched to avoid the blow but it was useless. Okonkwo's machete descended twice and the man's head lay beside his uniformed body. He wiped his machete on the sand and went away. The story says that he went to hang himself in a branch tree behind his compound. We are told that he was not buried by the clansmen and his death was not mourned as he committed an abomination against the Igbo custom.
Then they came to the tree from which Okonkwo's body was dangling, and they stopped dead. "Perhaps your men can help us bring him down and bury him," said Obierika. "Why can't you take him down yourselves?" he asked. "It is against our custom," said one of the men. "It is an abomination for a man to take his own life. It is an offence against the Earth, and a man who commits it will not be buried by his clansmen. His body is evil, and only strangers may touch it. That is why we ask your people to bring him down, because you are strangers." "Will you bury him like any other man?" asked the Commissioner. "We cannot bury him. Only strangers can. We shall pay your men to do it. When he has been buried we will then do our duty by him. We shall make sacrifices to cleanse the desecrated land."(Achebe, 1958)

Despite that Okonkwo grew up extraordinarily, achieving rank and fame from time to time, there is a likelihood to conclude that his admiration culminated into a deep fall resulting from a tragic flaw starting from the death of the young Ikemefuna. The fact that Okonkwo is proud of the boy but never admits it openly is a tragic flaw of the character as he believed that to openly admit the affection is cowardice. When the time comes to kill the boy Ikemefuna, as a leader of the clan, Okonkwo takes part in the killing. This is the point of undoing for him. In order not to appear weak, he assists the people in execution of the oracle. The killing initiates a series of conflicts. It is the beginning of the downfall of the protagonist (Rajeshwari \& Bhuvaneshwari, 2016). In Aristotelian theory, it is that stage he termed "Flaw" or error of judgment (hamartia) which, in connection with the character's destiny, causes a drastic fall resulting in a tragic end.

Shaka is concerned with some of Booker's stages of the tragic hero as an unwanted heir. This is something missing and it follows that with his dream to be an exceptional leader, he tasted the ills of exile but later rose into an unequalled military genius among his peers and a consummate leader. The tragic hero frustration goes along with his mother's death. Right about here is where the tragic hero hits his first roadblocks. They might be small annoyances, but in dealing with them, the protagonist commits additional dark acts that 
seal his fate and alert the reader that the only way this can end is badly. Next is nightmare stage connected with the long shadows of death as we are told that the tragic events in the life of Shaka accumulate, and is often in a dark mood particularly because his mother - his twin spirit in the Zulu sense- is constantly ailing but also many constant deaths among those he loves (1979: 273). In Booker's view, in this case the tragic hero's plan is unraveling, and he can sense that an opposing force or fate is closing in and destruction or death is inevitable. His death was planned long before. It is rooted in his closer relatives' hatred. His paternal aunt, Mkabhayi, in collaboration with his brothers plotted against him and death was inevitable. Shaka's overconfidence could not let him pay attention to Pampata's words as Ritter (1965:110) says that again and again Pampata warned Shaka not to go without guards. In Pampata's view, those whom he treated badly or ambitious persons who would like to take his place could endanger his life. Contrary, Shaka said: -my brothers have no ambitions. Moreover, I have treated them well, so why should they turn against me? In any case they are both afraid of me. As matter of fact, Shaka's excess confidence in his relatives rejected Pampata's advices. In Aristotelian terms of a tragic hero, this is excessive pride (hubris) or weakness. He did not know that, according to Ngugi (1967:173), ones' betrayers are among themselves. Those he trusted were sheep into wolves' clothes and they killed him. Perhaps, this was then his ripe time despite his invulnerability all along his life. Despite many wars he won, the black dangerous snake he killed when he was still a teenager and the leopard he got rid of himself, besides the Mad Giant or forest bandit he overcame, failure to listen to Pampata made his blood spurt out. Kunene (1979: 425) tells it that Shaka's brothers appeared, accompanied by their followers. They rushed after him as he attempted to reach his weapon, stabbed him from all sides and blood spurted outside even from his mouth. It is a tragic death as Aristotelian theory holds it. We can see Shaka is saying his last words telling his brothers: "--So my brothers, you are killing me? You think you shall rule Zululand after my death? No, you shall never rule. Only the swallowers shall rule over it." Shaka's words reflect Aristotelian tragic hero who, according to him, dies a tragic death, having fallen from great heights and having made an irreversible mistake, the hero who courageously accepts their death with honour. In Brooker's theory, this is destruction stage where a hero breaths last in his enemies hands. Had he listened to Pampata, Dingane and Mhlangara would not have killed him. Had he his short spear at that time, the plan of his killers would abort and they would be ashamed, but it was otherwise as he made an irreversible mistake according to Aristotelian theory of the tragic hero. Probably fate is like that. At this point, one can conclude that Shaka's story reflects a tragic flaw which, in the view of Rajeshwari\&Bhuvaneshwari, (2016) is an attribute of a character that ultimately leads to the demise of that character while Foley (2001) opines that Okonkwo's fate may be interpreted as mere blind chance, and that Okonkwo may be regarded as a victim of the accidents of history, of the arbitrary events of a purely material existence.

\section{CONCLUSION}

The main purpose of this study was to compare two literary works basing on their heroic characters' description each. The study explored the tragic fall of the two main characters Okonkwo and Shaka. A dual theoretical frame was used namely Christopher Booker's basic stages of the tragic flaw and Aristotelian theory of the tragic hero. Literary analysis as the scientific method was used to cement the discussion. As literary critics analyze literature or the authors of literature to find truths about the world, studies on African literature and African writers convey various messages (Bazimaziki, 2017) basing on the protagonists. Findings in this study reflect it in that analysis revealed that Okonkwo and Shaka are heroic characters meeting at two levels: Fame or admiration and fall. They are important characters and depicted historical figures often time encountered in African literary works. Initially, both heroes underwent fame and admiration. Later, their power dwindled drastically until they died sudden deaths. Each of the two committed a crime or an error of judgement that endangered their lives. Okonkwo committed suicide as a result of failure to understanding his blind fate or of some kind of pre-ordained destiny as a victim of the accidents of history (Foley, 2001). Shaka's drastic fall is a result of overconfidence and neglect. He rejected his advisor, Pampata, who told him what had been planned against him but in vain. Fate is as such that if it was planned that so and so would undergo the ups and downs in his life, human power can alter or do nothing against it. Though it is often said that heroes never die but sleep, the two characters may convey the message that self-confidence is good but overconfidence is somehow not always beneficial and " had I known is never profitable". If Okonkwo were still there too, one would tell him that "experience is the best instructor". Taken together, this single study could not cover all the aspects of literary criticism with emphasis on the two historical personages. Further studies can bridge such gap basing on psychological analysis of the two protagonists.

\section{ACKNOWLEDGEMENT}


The author would like to acknowledge whoever played any part in this paper in one way or another.

\section{REFERENCES}

[1] Achebe, Chinua (1958). Things Fall Apart. Nairobi: Heinemann

[2] Bazimaziki, Gabriel (2017) Depiction of human society through epic literary genres: A comparative perspective of the function of two African heroic epics. International Journal of English and Literature. 8(5). pp 63-73

[3] Booker, C.(2006) The Seven Basic Plots. Why we tell stories. London: Bloomsbur

[4] Brown. Bakhtin, M.M. (1981).The Epic and the Novel: Towards a Methodology for the Study in the Novel. The Dialogic Imagination. Austin: University of Texas Press.

[5] Deme, Mariam K.(2009). Heroism and the Supernatural in the African Epic: Toward a Critical Analysis. Journal of Black Studies 39 (3): 402-19.

[6] Durosimi Eldred Jones, Palmer Eustache, \& Marjorie Jones (Eds.) Orature in African Literature Today. London: African World Press, Vol. 18.pp.6. 80

[7] Foley, A.(2001) Okonkwo's fate and the worldview of Things Fall Apart. Literator 22(2)39- 59. Retrieved from

http://www.penguinrandomhouse.com/books/565351/t hings-fall-apart-by-chinua-achebe/9780679446231.

ISSN 0258-2279

[8] Gill, Richard (1995). Mastering English Literature. New York: Palgrave.

[9] Harmon William and Holman Hugh (1992). A Handbook to Literature. 10th Ed. New York: Macmillan.

[10] Hogins, James B. (1984). Literature.3rd Ed. Chicago: Science Research Associate.

[11]Elliot, J. \& Hawker, S. (1999) Concise Oxford Dictionary.

[12] Kesteloot ,Lilyan (1989). The African Epic author(s). African Languages and Cultures. Vol.2, No. 2 pp. 203214 Published by: Taylor \& Francis. Available from http://www.jstor.org/stable/1771787.

[13] Kesteloot, Lilyan and BassirouDieng. (1997). Les épopées d'Afrique Noire. Paris: Editions Karthala.

[14] Kesteloot, Lylian (ed.) (1971). L'EpopéeTraditionnelle. Paris: Fern Nathan.

[15] Kunene, M. (1979). Emperor Shaka the Great, A Zulu Epic. London: Heinemann
[16] Mbele Joseph (2005) Notes on Achebe's Things Fall Apart. Africonection: Minnesota [On line] Available from http://www.africonection.com [Retrieved on $7^{\text {th }}$ October 2017].

[17] Muich, Rebecca M. (2010). Pouring out our tears: Andromache in Homer and Euripides. Illinois: University of Illinois (A Doctoral Thesis).

[18] Mulokozi M., M. (2002). The African Epic Controversy: Historical, Philosophical, and Aesthetic Per-spectives on Epic Poetry and Performances. Dar es Salaam: MkukinaNyota Publishers.

[19] Mulokozi, M., M. (2002) The African epic controversy. Journal of Folklore. New York: Walter de Gruyter.

[20] Mulokozi, M., M. (1992). Nordic Journal of African Studies 1 (2): 71-80. University of Dar es Salaam, Tanzania.

[21] Niane, D.T. (1965). Sundiata: An Epic of Old Mali. London: Longman.

[22] Ngugi Wa Thiong'o (1967) A Grain of Wheat. Nairobi: East African Educational Publishers.

[23] Okpewho, I. (1979). The Epic in Africa. New York: CUP.

[24] Oxford Advanced Learner's Dictionary (2015) (8 (th $^{\text {th }}$ $E d$.). Oxford: Oxford University Press.

[25] Rajeshwari, R. S. \& Bhuvaneshwari R. S. (2016) Tragic dimension in Chinua Achebe's Things Fall Apart. Pune Research Discovery: An International Journal of Advanced Studies. 1 (2)

[26] Ritter, I, A. (1964). Shaka Zulu. London: Green.

[27] Rummell, K. (2002). Toni Morrison's "Beloved": Transforming the African heroic epic. The Griot 21(1).

[28] Scholes, Robert (1978). Elements of Literature: Essay, Fiction, Poetry, Drama, Film. New York: Oxford University.

[29] Schweizer, Bernard (ed.) (2006). Approaches to the Anglo and American Female Epic, 1621-1982. Hamphshire: Ashgate. ISBNO754654869. Available from http://www.ashgate.com [Retrieved on 25th August 2012 at 6:30 p.m].

[30] Sporre, J. Dennis (1998). The Literary Spirit. New Jersey: Prentice Hall.

[31] World Book Encyclopedia (2016), Vol.22 (Online) available fromhttps://www.amazon.com/World-BookEncyclopedia-2016-Set/dp/0716601168

[32] Wright, D. (1957) Beowulf (trans.) New York: Penguin Book. 